\title{
Determinan Kesehatan Mental Anak Yatim dan Piatu di Lembaga Kesejahteraan Sosial Anak Kabupaten Bireuen
}

\section{Determinants Of Mental Health Of Orphants In Children's Social Welfare Institution, Bireuen District}

\author{
Sri Raudhati ${ }^{1}$, Marthoenis ${ }^{2}$, Aulina Adamy ${ }^{3}$ \\ ${ }^{1,3}$ Magister Kesehatan Masyarakat, Universitas Muhammadiyah Aceh, Banda Aceh \\ ${ }^{2}$ Fakultas Keperawatan, Universitas Syiah Kuala, Banda Aceh \\ Email: sriraudhati@gmail.com ${ }^{1}$, marthoenis@unsyiah.ac.id ${ }^{2}$, aulinaunmuha@gmail.com ${ }^{3}$
}

\begin{abstract}
Abstrak
Latar Belakang: WHO menyebutkan, gangguan kesehatan mental lebih rentan menyerang kalangan generasi milenial, dan gangguan kesehatan mental paling rentan terjadi pada remaja yatim piatu yang tinggal di panti asuhan, karena kehilangan cinta dan perhatian langsung dari ayah dan ibu kandungnya. Tujuan dari penelitian ini adalah untuk mengetahui faktor yang berhubungan dengan kesehatan mental anak yatim, piatu, dan yatim piatu di Lembaga Kesejahteraan sosial anak Kabupaten Bireuen. Metode: Penelitian ini merupakan penelitian kuantitatif, menggunakan rancangan penelitian cross sectional. Populasi penelitian adalah anak yatim dan piatu yang berada di Panti Asuhan Kabupaten Bireuen, dan penarikan sampel menggunakan teknik purposive sampling, dengan jumlah sampel sebanyak 104 anak. Uji statistik yang digunakan dalam analisis data adalah uji regresi logistik menggunakan program stata 15. Hasil: Diperoleh bahwa $25 \%$ anak mengalami masalah kesulitan perilaku dan emosional, dimana proporsi terbesar adalah masalah teman sebaya (31.7\%), selanjutnya gejala emosional $(27.9 \%)$, masalah perilaku (19.2\%), dan hiperaktivitas (7.7\%), sedangkan masalah penurunan perilaku prososial anak sebanyak $14.4 \%$. Hasil uji logistik multivariat menunjukkan bahwa faktor jenis kelamin perempuan, alasan lainnya, usia anak saat maninggal orangtua $\leq 5$ tahun, dan keluarga yang jarang berkunjung memiliki hubungan yang signifikan terhadap kesulitan masalah perilaku dan emosional $(P=0.004 ; P=0.012 ; P=0.007 ; P=0.003$ secara berurutan), sedangkan faktor yang memiliki hubungan signifikan dengan perilaku prososial adalah faktor alasan lainnya saat masuk panti, status anak piatu, kondisi kesehatan anak yang sakit, dan anak yang mengalami konflik $(P=0.031 ; P=0.010, P=0.011 ; P=0.002$ secara berurutan). Kesimpulan: Terdapat hubungan yang bermakna antara jenis kelamin, alasan masuk panti, status anak, kunjungan keluarga, kondisi kesehatan anak, dan pengalaman konflik dengan kesehatan mental anak yatim dan piatu.
\end{abstract}

Kata Kunci: Kesehatan Mental, Yatim Piatu, LKSA

\begin{abstract}
Background: WHO said that mental health disorders are more prone to attack the millennial generation, and mental health disorders are most vulnerable to orphaned adolescents living in orphanages, because they have lost love and direct attention from their biological fathers and mothers. The purpose of this study was to determine the factors related to the mental health of orphans in the Bireuen District Child Welfare Institution. Method: This research is a quantitative study, using a cross sectional study design. The study population was orphans who were in the Bireuen orphanage, and the samples were taken using purposive sampling technique, with a total sample of 104 children. The statistical test used in the data analysis was the logistic regression test using the stata program 15. Results: It was found that $25 \%$ of children experienced behavioral and emotional difficulties, where the largest proportion was peer problems (31.7\%), then emotional symptoms (27.9\%), behavioral problems (19.2\%), and hyperactivity (7.7\%), while the problem of decreasing children's prosocial behavior was $14.4 \%$. The results of the multivariate logistic test showed that female gender, other reasons, the child's age at the death of their parents $\leq 5$ years, and families who rarely visited had a significant relationship with behavioral and emotional difficulties $(P=0.004 ; P=0.012 ; P=0.007$ $; P=0.003$ respectively), While the factors that had a significant relationship with prosocial behavior were other reasons for entering the orphanage, the status of the orphaned children, the health condition of the sick children, and the children who experienced conflicts $(P=0.031 ; P=0.010, P=0.011 ; P=0.002$ respectively). Conclusion: There is a significant relationship between gender, reasons for entering the institution, children's status, family visits, children's health conditions, and experiences of conflict with the mental health of orphans and orphans.
\end{abstract}

Keywords: Mental Health, Orphans, Children's Social Welfare Institution 


\section{Pendahuluan}

Kesehatan mental merupakan salah satu hal yang penting bagi perkembangan kesehatan anak dan remaja dan menjadi fokus kesehatan global dalam kaitannya dengan penderitaan, cacat fungsi, paparan stigma diskriminasi, hingga potensi kematian ${ }^{4,19}$. Berdasarkan data epidemiologi global, sekitar $12-13 \%$ anak dan remaja menderita gangguan mental ${ }^{11}$, dan sekitar 14 juta anak usia 15 tahun ke atas atau 6\% dari jumlah penduduk Indonesia mengalami gejalagejala depresi dan kecemasan ${ }^{10}$.

Anak yatim, piatu, atau yatim piatu merupakan anak yang kehilangan salah satu atau kedua orangtua kandung sebelum dia baligh dan dewasa (Kementerian Agama RI, 2010). Dari 153 juta anak yatim piatu di seluruh dunia, sebanyak 145 juta orang tinggal di negara-negara berpenghasilan rendah, dan frekuensinya terus meningkat secara dramatis karena kasus HIV/AIDS dan penyebab lainnya ${ }^{18}$. Kebutuhan mereka tidak terpenuhi dengan baik, seperti kebutuhan sosial, pendidikan, dan perawatan kesehatan yang mencakup tempat tinggal yang memadai, pendidikan, dukungan nutrisi, dukungan psikososial, dan perawatan kesehatan ${ }^{17}$.

Merujuk pada data hasil Riset Kesehatan Dasar (Riskesdas) tahun 2018, didapatkan bahwa prevalensi penderita skizofrenia atau psikosis sebesar 7 per 1000 dengan cakupan pengobatan $84,9 \%$. Sementara itu, prevalensi gangguan mental emosional pada remaja berumur 15 tahun ke atas sebesar 9,8\%. Angka ini meningkat dibandingkan tahun 2013 yaitu sebesar 6\%. Kabupaten Bireuen menurut Riskesdas (2018), prevalensi gangguan mental emosional pada penduduk usia 15 tahun ke atas berada pada urutan ke 8 setelah Aceh Tenggara dengan persentase $9.57 \%$, angka ini lebih tinggi dari persentase Provinsi Aceh (8.96\%) ${ }^{9}$.

Gangguan kesehatan mental paling rentan terjadi pada remaja yatim piatu yang tinggal di panti asuhan. Penelitian sebelumnya menunjukkan bahwa gangguan kesehatan mental pada anak yatim piatu lebih tinggi dibandingkan dengan remaja non yatim piatu ${ }^{2,7,13}$. Penelitian menunjukkan remaja yang tinggal di panti asuhan terpapar berbagai gangguan emosi seperti depresi, kecemasan dan stres $1,12,13$.

Penelitian lain menunjukkan bahwa bahwa prevalensi masalah mental emosional dan perilaku anak/remaja yang tinggal di Panti Asuhan lebih tinggi dibandingkan dengan anak/remaja seusianya yang dibesarkan dalam lingkungan keluaga inti ${ }^{16}$. Anak yatim yang tinggal di panti asuhan lebih rentan terhadap masalah perilaku dan emosional, karena mereka kehilangan cinta dan perhatian langsung dari ayah atau ibu kandungnya. Faktor-faktor seperti usia, jenis kelamin, alasan berada di panti, usia anak masuk ke panti, dan tahun tinggal, semuanya berhubungan secara signifikan $(\mathrm{P}<0,05)$ dengan masalah emosional dan perilaku. Walaupun anak yatim mendapatkan orangtua pengganti (pengasuh anak), namun tidak selamanya keluarga pengganti yang diperoleh di panti asuhan dapat membantu perkembangan mental anak ${ }^{6}$. Beberapa masalah psikososial lainnya yang sering dihadapai remaja saat ini seperti kesulitan belajar, penyalahgunaan NAPZA, seks bebas, dan perilaku berisiko lainnya ${ }^{8}$. Berdasarkan latar belakang masalah tersebut, penelitian terkait kesehatan mental anak yatim piatu di Kabupaten Bireuen perlu dilakukan. Penelitian ini bertujuan untuk mengetahui faktor yang berhubungan dengan kesehatan mental anak yatim, piatu, dan yatim piatu di Lembaga Kesejahteraan sosial anak Kabupaten Bireuen.

\section{Metode Penelitian}

Penelitian ini merupakan penelitian kuantitatif menggunakan rancangan penelitian cross sectional. Populasi dalam penelitian ini adalah seluruh anak yatim, piatu, dan yatim piatu yang berada pada 4 Lembaga Kesejahteraan Sosial Anak. Pengambilan sampel secara purposive sampling, dan diperoleh besar sampel sebanyak 104 anak.

Instrument penelitian yang digunakan adalah Strength and Difficulties Questionnaire (SDQ) untuk mengukur kesehatan mental anak dan The Multidimensional Scale of Perceived 
Social Support (MSPSS) untuk mengukur dukungan sosial pada anak ${ }^{8,22}$. Analisis data menggunakan uji regresi logistic menggunakan prosedur logit program Stata 15.

\section{Hasil}

\section{A. Analisis Univariat}

Hasil analisis univariat karakteristik dan kesehatan mental anak anak yatim, piatu dan yatim piatu di Lembaga Kesejahteraan Sosial Anak (LKSA) Kabupaten Bireuen secara deskriptif dapat dilihat pada tabel analisis univariat sebagai berikut:

Tabel 1. Sosial Demografi dan Kesehatan Mental (Kesulitan dan Kekuatan Mental Emosional) Anak Yatim dan Piatu di Lembaga Kesejahteraan Sosial Anak Kabupaten Bireuen ( $n=104)$

\begin{tabular}{|c|c|c|}
\hline Variabel/Kategori & $\mathbf{n}$ & $\%$ \\
\hline $\begin{array}{l}\text { Jenis Kelamin: } \\
\text { a. Laki-Laki } \\
\text { b. Perempuan }\end{array}$ & $\begin{array}{l}39 \\
65\end{array}$ & $\begin{array}{l}37.5 \\
62.5\end{array}$ \\
\hline $\begin{array}{l}\text { Pendidikan: } \\
\text { a. SLTP } \\
\text { b. SLTA }\end{array}$ & $\begin{array}{l}31 \\
73\end{array}$ & $\begin{array}{l}29.8 \\
70.2\end{array}$ \\
\hline $\begin{array}{l}\text { Usia Pertama Masuk Panti: } \\
\text { a. } 13-18 \text { tahun } \\
\text { b. }<13 \text { tahun }\end{array}$ & $\begin{array}{l}47 \\
57\end{array}$ & $\begin{array}{l}45.2 \\
54.8\end{array}$ \\
\hline $\begin{array}{l}\text { Alasan Tinggal di Panti: } \\
\text { a. Keinginan sendiri } \\
\text { b. Meninggal Orangtua } \\
\text { c. Lainnya (Melanjutkan pendidikan, disuruh } \\
\text { Ibu/Ayah, Tidak mampu) }\end{array}$ & $\begin{array}{l}26 \\
41 \\
37\end{array}$ & $\begin{array}{l}25.0 \\
39.4 \\
35.6\end{array}$ \\
\hline $\begin{array}{l}\text { Usia Yatim Piatu: } \\
\text { a. } \leq 5 \text { tahun } \\
\text { b. } 6-10 \text { tahun } \\
\text { c. } 11-18 \text { tahun }\end{array}$ & $\begin{array}{l}22 \\
34 \\
48\end{array}$ & $\begin{array}{l}21.2 \\
32.7 \\
46.1\end{array}$ \\
\hline $\begin{array}{l}\text { Status Anak: } \\
\text { a. Yatim } \\
\text { b. Piatu } \\
\text { c. Yatim piatu }\end{array}$ & $\begin{array}{c}80 \\
17 \\
7\end{array}$ & $\begin{array}{c}76.9 \\
16.4 \\
6.7 \\
\end{array}$ \\
\hline $\begin{array}{l}\text { Kondisi Kesehatan Fisik: } \\
\text { a. Sehat } \\
\text { b. Sakit }\end{array}$ & $\begin{array}{c}99 \\
5\end{array}$ & $\begin{array}{c}95.2 \\
4.8\end{array}$ \\
\hline $\begin{array}{l}\text { Jumlah Saudara Kandung: } \\
\text { a. Tidak ada } \\
\text { b. } 2-3 \text { bersaudara } \\
\text { c. } \geq 4 \text { bersaudara }\end{array}$ & $\begin{array}{l}12 \\
39 \\
53\end{array}$ & $\begin{array}{l}11.5 \\
37.5 \\
60.0\end{array}$ \\
\hline $\begin{array}{l}\text { Dukungan Sosial: } \\
\text { a. Tinggi } \\
\text { b. Sedang } \\
\text { c. Kurang }\end{array}$ & $\begin{array}{c}2 \\
68 \\
13\end{array}$ & $\begin{array}{l}22.1 \\
65.4 \\
12.5\end{array}$ \\
\hline $\begin{array}{l}\text { Frekuensi Kunjungan Keluarga: } \\
\text { a. Selalu } \\
\text { b. Sering }\end{array}$ & $\begin{array}{l}27 \\
42\end{array}$ & $\begin{array}{c}26 \\
40.4\end{array}$ \\
\hline
\end{tabular}


Tabel 1. Sosial Demografi dan Kesehatan Mental (Kesulitan dan Kekuatan Mental Emosional) Anak Yatim dan Piatu di Lembaga Kesejahteraan Sosial Anak Kabupaten Bireuen (n=104)

\begin{tabular}{lcc}
\hline \multicolumn{1}{c}{ Variabel/Kategori } & n & \% \\
\hline c. Jarang & 35 & 33.6 \\
\hline Pengalaman Konflik: & 98 & 94.23 \\
a. Tidak mengalami & 6 & 5.77 \\
b. Mengalami & 78 & \\
\hline Total Skor Kesulitan: & 26 & 75.0 \\
a. Normal & & 25.0 \\
b. Abnormal & 75 & 72.1 \\
\hline Gejala Emosional: & 29 & 27.9 \\
a. Normal & & \\
b. Abnormal & 84 & 80.8 \\
\hline Masalah Perilaku: & 20 & 19.2 \\
a. Normal & & \\
b. Abnormal & 96 & 92.3 \\
\hline Hiperaktivitas: & 8 & 7.7 \\
a. Normal & & \\
b. Abnormal & 71 & 68.3 \\
\hline Masalah Teman Sebaya: & 33 & 31.7 \\
a. Normal & & \\
b. Abnormal & 87 & 16.4 \\
\hline Total Skor Kekuatan/Prososial: & 17 & \\
a. Normal & & \\
b. Abnormal & &
\end{tabular}

Tabel 1, menunjukkan bahwa karakteristik anak dari total dari 104 anak paling dominan adalah jenis kelamin perempuan (62.5\%), anak yang berada pada jenjang pendidikan SLTP adalah $70.2 \%$, usia pertama masuk panti paling dominan adalah usia $<13$ tahun (54.8\%), alasan anak yang tinggal di panti mayoritas karena meninggal orangtua $39.4 \%$, usia anak saat orangtua meninggal mayoritas pada usia $\leq 5$ tahun $(46.1 \%)$, status anak yang tinggal di panti paling dominan adalah anak yatim $(76.9 \%)$.

Hasil penelitian berdasarkan tabel 1, menunjukkan bahwa ada $4.8 \%$ anak yang sakit (demam, sakit kepala, sakit gigi, flu dan batuk), jumlah saudara kandung mayoritas $\geq 4$ bersaudara (50.96\%). Terdapat 5.77\% anak yang pernah mengalami pengalaman konflik (anak yang orangtuanya merupakan korban konflik senjata di Aceh, dan juga anak korban konflik dalam keluarga). Selama tinggal di panti mayoritas keluarga sering melakukan kunjungan ke panti asuhan $(40.4 \%)$, dan terdapat $12.5 \%$ anak yang kurang mendapat dukungan sosial selama berada di panti.

Berdasarkan tabel 1 di atas, dapat diketahui bahwa total skor kesulitan mental emosional pada anak sebesar 25\%, dengan gejala emosional $27.9 \%$, masalah perilaku $19.2 \%$. Hiperaktivitas $7.7 \%$, masalah teman sebaya $31.7 \%$, sedangkan penurunan perilaku prososial anak sebanyak $16.4 \%$. 
B. Analisis Bivariat

1. Hubungan Faktor Risiko dengan Kesulitan Mental Emosional Anak

Hasil uji statistik antara faktor risiko dengan kesulitan mental emosional anak yatim di Lembaga Kesejahteraan Sosial Anak Kabupaten Bireuen dapat disajikan dalam tabel 3, sebagai berikut:

Tabel 2. Analisis Bivariat Regresi Logistik Kesulitan Mental Emosional Anak Yatim dan Piatu di Lembaga Kesejahteraan Sosial Anak Kabupaten Bireuen ( $\mathrm{N}=104)$

\begin{tabular}{|c|c|c|c|c|c|c|c|c|}
\hline \multirow{3}{*}{ Variabel/Kategori } & \multicolumn{4}{|c|}{ Kesulitan } & \multirow{2}{*}{\multicolumn{2}{|c|}{ Total }} & \multirow{3}{*}{$\begin{array}{c}\text { OR } \\
(\mathrm{CI} 95 \%)\end{array}$} & \multirow{3}{*}{$\begin{array}{c}\mathbf{P} \\
\text { Value }\end{array}$} \\
\hline & \multicolumn{2}{|c|}{ Normal } & \multicolumn{2}{|c|}{ Abnormal } & & & & \\
\hline & $\mathbf{n}$ & $\%$ & $\mathbf{n}$ & $\%$ & $\mathbf{n}$ & $\%$ & & \\
\hline \multicolumn{9}{|l|}{ Jenis kelamin: } \\
\hline Laki-laki & 36 & 92.3 & 3 & 7.7 & 39 & 100.0 & - & - \\
\hline Perempuan & 42 & 64.7 & 23 & 35.4 & 65 & 100.0 & $\begin{array}{c}6.57 \\
(1.82-23.70)\end{array}$ & 0.004 \\
\hline \multicolumn{9}{|l|}{ Pendidikan: } \\
\hline SLTA & 27 & 87.1 & 4 & 12.9 & 31 & 100.0 & - & - \\
\hline SLTP & 51 & 69.9 & 22 & 30.1 & 73 & 100.0 & $\begin{array}{c}2.91 \\
(0.91-9.31)\end{array}$ & 0.072 \\
\hline \multicolumn{9}{|l|}{ Usia Masuk Panti: } \\
\hline 13-18 tahun & 33 & 70.2 & 14 & 29.8 & 47 & 100.0 & - & - \\
\hline$<13$ tahun & 45 & 79.0 & 12 & 21.0 & 57 & 100.0 & $\begin{array}{c}0.63 \\
(0.26-1.53)\end{array}$ & 0.308 \\
\hline \multicolumn{9}{|l|}{ Alasan Masuk Panti: } \\
\hline Keinginan sendiri & 24 & 92.3 & 2 & 7.7 & 26 & 100.0 & - & - \\
\hline Meninggal Ortu & 33 & 80.5 & 8 & 19.5 & 41 & 100.0 & $\begin{array}{c}2.91 \\
(0.57-14.94)\end{array}$ & 0.201 \\
\hline Lainnya & 21 & 56.8 & 16 & 43.2 & 37 & 100.0 & $\begin{array}{c}9.14 \\
(1.87-44.49)\end{array}$ & 0.006 \\
\hline \multicolumn{9}{|l|}{ Usia yatim piatu: } \\
\hline 11-18 tahun & 19 & 86.4 & 3 & 13.6 & 22 & 100.0 & - & - \\
\hline 6-10 tahun & 28 & 82.3 & 6 & 17.7 & 34 & 100.0 & $\begin{array}{c}1.36 \\
(0.30-6.10)\end{array}$ & 0.691 \\
\hline$\leq 5$ tahun & 31 & 64.6 & 17 & 35.4 & 48 & 100.0 & $\begin{array}{c}3.47 \\
(0.30-6.10)\end{array}$ & 0.071 \\
\hline \multicolumn{9}{|l|}{ Status anak: } \\
\hline Yatim & 60 & 75.0 & 20 & 25.0 & 80 & 100.0 & - & - \\
\hline Piatu & 14 & 82.4 & 3 & 17.6 & 17 & 100.0 & $\begin{array}{c}0.64 \\
(0.17-2.47) \\
\end{array}$ & 0.520 \\
\hline Yatim piatu & 4 & 57.1 & 3 & 42.9 & 7 & 100.0 & $\begin{array}{c}2.25 \\
(0.46-10.93)\end{array}$ & 0.314 \\
\hline \multicolumn{9}{|c|}{ Kondisi kesehatan anak: } \\
\hline Sehat & 76 & 76.8 & 23 & 23.2 & 99 & 100.0 & - & - \\
\hline Sakit & 2 & 40.0 & 3 & 60.0 & 5 & 100.0 & $\begin{array}{c}4.96 \\
(0.78-31.49)\end{array}$ & 0.09 \\
\hline \multicolumn{9}{|l|}{ Jumlah saudara: } \\
\hline Tidak ada & 9 & 75.0 & 3 & 25.0 & 12 & 100.0 & - & - \\
\hline 2-3 bersaudara & 34 & 87.2 & 5 & 12.8 & 39 & 100.0 & 0.44 & 0.319 \\
\hline
\end{tabular}


Tabel 2. Analisis Bivariat Regresi Logistik Kesulitan Mental Emosional Anak Yatim dan Piatu di Lembaga Kesejahteraan Sosial Anak Kabupaten Bireuen ( $N=104)$

\begin{tabular}{|c|c|c|c|c|c|c|c|c|}
\hline \multirow{4}{*}{ Variabel/Kategori } & \multicolumn{4}{|c|}{ Kesulitan } & \multirow{2}{*}{\multicolumn{2}{|c|}{ Total }} & \multirow{3}{*}{$\begin{array}{c}\text { OR } \\
\text { (CI 95\%) }\end{array}$} & \multirow{4}{*}{$\begin{array}{c}\mathbf{P} \\
\text { Value }\end{array}$} \\
\hline & \multicolumn{2}{|c|}{ Normal } & \multicolumn{2}{|c|}{ Abnormal } & & & & \\
\hline & $\mathbf{n}$ & $\%$ & $\mathbf{n}$ & $\%$ & $\mathrm{n}$ & $\%$ & & \\
\hline & & & & & & & $(0.88-2.20)$ & \\
\hline$\geq 4$ bersaudara & 35 & 66.0 & 18 & 34.0 & 53 & 100.0 & $\begin{array}{c}1.54 \\
(0.37-6.41)\end{array}$ & 0.551 \\
\hline \multicolumn{9}{|l|}{ Pengalaman konflik: } \\
\hline Tidak mengalami & 75 & 76.5 & 23 & 23.5 & 98 & 100.0 & - & - \\
\hline Mengalami & 3 & 50.0 & 3 & 50.0 & 6 & 100.0 & $\begin{array}{c}3.26 \\
(0.61-17.27)\end{array}$ & 0.165 \\
\hline \multicolumn{9}{|l|}{ Kunjungan Keluarga: } \\
\hline Selalu & 25 & 92.6 & 2 & 7.4 & 27 & 100.0 & - & - \\
\hline Sering & 32 & 76.2 & 10 & 23.8 & 42 & 100.0 & $\begin{array}{c}3.91 \\
(0.78-19.46)\end{array}$ & 0.096 \\
\hline Jarang & 21 & 60.0 & 14 & 40.0 & 35 & 100.0 & $\begin{array}{c}8.33 \\
(1.69-40.91) \\
\end{array}$ & 0.009 \\
\hline \multicolumn{9}{|l|}{ Dukungan sosial: } \\
\hline Tinggi & 16 & 69.6 & 7 & 30.4 & 23 & 100.0 & - & - \\
\hline Sedang & 54 & 79.4 & 14 & 20.6 & 68 & 100.0 & $\begin{array}{c}0.59 \\
(0.20-1.72)\end{array}$ & 0.336 \\
\hline Rendah & 8 & 61.5 & 5 & 38.5 & 13 & 100.0 & $\begin{array}{c}1.43 \\
(0.34-5.95)\end{array}$ & 0.624 \\
\hline
\end{tabular}

Berdasarkan Tabel 2, dapat diketahui bahwa, terdapat hubungan yang signifikan antara jenis kelamin, alasan masuk panti asuhan, dan frekuensi kunjungan keluarga. Hasil uji statistik menunjukkan bahwa risiko kesulitan mental emosional pada anak perempuan 6.57 kali lebih besar dibandingkan pada anak laki-laki. $(\mathrm{OR}=6.57 ; 95 \% \mathrm{CI}=1.82-23.70 ; p$ value $=0.004)$, alasan anak masuk panti asuhan karena alasan lainnya 2.91 kali lebih terpapar mengalami kesulitan mental emosional dibandingkan karena alasan keinginan sendiri dan meninggal orangtua $(\mathrm{OR}=2.91 ; 95 \% \mathrm{CI}=1.88-44.49 ; p$ value $=0.006)$, dan anak yang jarang dikunjungi keluarga memilki risiko kesulitan mental emosional 8.33 kali lebih besar dibandingkan dengan jumlah kunjungan lainnya $(\mathrm{OR}=8.33 ; 95 \% \mathrm{CI}=1.69-40.91 ; p$ value $=0.009)$.

\section{Hubungan Faktor Risiko dengan Kekuatan/Perilaku prososial Anak}

Hasil uji statistik antara faktor risiko dengan kekuatan (perilaku prososial) anak yatim di Lembaga Kesejahteraan Sosial Anak Kabupaten Bireuen dapat disajikan dalam tabel 3 sebagai berikut: 
Tabel 3. Analisis Bivariat Regresi Logistik Kekuatan/Perilaku Prososial Anak Yatim dan Piatu di Lembaga Kesejahteraan Sosial Anak Kabupaten Bireuen (n=104)

\begin{tabular}{|c|c|c|c|c|c|c|c|c|c|}
\hline \multirow{3}{*}{ No } & \multirow{3}{*}{ Variabel/Kategori } & \multicolumn{4}{|c|}{ Kekuatan } & \multirow{2}{*}{\multicolumn{2}{|c|}{ Total }} & \multirow{3}{*}{$\begin{array}{c}\text { OR } \\
\text { (CI 95\%) }\end{array}$} & \multirow{3}{*}{$\begin{array}{c}P \\
\text { Value }\end{array}$} \\
\hline & & \multicolumn{2}{|c|}{ Normal } & \multicolumn{2}{|c|}{ Abnormal } & & & & \\
\hline & & $\mathbf{n}$ & $\%$ & $\mathbf{n}$ & $\%$ & n & $\%$ & & \\
\hline \multirow[t]{3}{*}{1} & Jenis kelamin: & & & & & & & & \\
\hline & Laki-laki & 35 & 89.7 & 4 & 10.7 & 39 & 100.0 & - & - \\
\hline & Perempuan & 52 & 80.0 & 13 & 20.0 & 65 & 100.0 & $\begin{array}{c}2.19 \\
(0.66- \\
7.26)\end{array}$ & 0.201 \\
\hline \multirow[t]{3}{*}{2} & Pendidikan: & & & & & & & & \\
\hline & SLTA & 27 & 87.1 & 4 & 12.9 & 31 & 100.0 & - & - \\
\hline & SLTP & 60 & 82.2 & 13 & 17.8 & 73 & 100.0 & $\begin{array}{c}1.46 \\
(0.44- \\
4.90) \\
\end{array}$ & 0.538 \\
\hline \multirow[t]{3}{*}{3} & Usia Masuk Panti: & & & & & & & & \\
\hline & 13-18 tahun & 40 & 85.1 & 7 & 14.9 & 47 & 100.0 & - & - \\
\hline & $<13$ tahun & 47 & 82.5 & 10 & 17.5 & 57 & 100.0 & $\begin{array}{c}1.22 \\
(0.42- \\
3.49) \\
\end{array}$ & 0.716 \\
\hline \multirow[t]{4}{*}{4} & Alasan Masuk Panti: & & & & & & & & \\
\hline & Keinginan sendiri & 26 & 100.0 & 0 & 0.0 & 26 & 100.0 & 1 & - \\
\hline & Meninggal Ortu & 35 & 85.4 & 6 & 14.6 & 41 & 100.0 & $\begin{array}{c}0.41 \\
(0.13- \\
1.24) \\
\end{array}$ & 0.113 \\
\hline & Lainnya & 26 & 70.3 & 11 & 29.7 & 37 & 100.0 & 1 & - \\
\hline \multirow[t]{4}{*}{5} & Usia yatim piatu: & & & & & & & & \\
\hline & 11-18 tahun & 18 & 81.8 & 4 & 18.2 & 22 & 100.0 & - & - \\
\hline & 6-10 tahun & 30 & 88.2 & 4 & 11.8 & 34 & 100.0 & $\begin{array}{c}0.60 \\
(0.13- \\
2.70) \\
\end{array}$ & 0.506 \\
\hline & $\leq 5$ tahun & 39 & 81.3 & 9 & 18.7 & 48 & 100.0 & $\begin{array}{c}1.04 \\
(0.28- \\
3.82) \\
\end{array}$ & 0.955 \\
\hline \multirow[t]{4}{*}{6} & Status anak: & & & & & & & & \\
\hline & Yatim & 72 & 90.0 & 8 & 10.0 & 80 & 100.0 & - & - \\
\hline & Piatu & 12 & 70.6 & 5 & 29.4 & 17 & 100.0 & $\begin{array}{c}3.75 \\
(1.05- \\
13.40) \\
\end{array}$ & 0.042 \\
\hline & Yatim piatu & 3 & 42.9 & 4 & 57.1 & 7 & 100.0 & $\begin{array}{c}12 \\
(2.27- \\
63.47) \\
\end{array}$ & 0.003 \\
\hline \multirow[t]{3}{*}{7} & Kondisi kesehatan anak: & & & & & & & & \\
\hline & Sehat & 85 & 85.9 & 14 & 14.1 & 99 & 100.0 & - & - \\
\hline & Sakit & 2 & 40.0 & 3 & 60.0 & 5 & 100.0 & $\begin{array}{c}9.11 \\
(1.39- \\
59.47) \\
\end{array}$ & 0.021 \\
\hline
\end{tabular}


Tabel 3. Analisis Bivariat Regresi Logistik Kekuatan/Perilaku Prososial Anak Yatim dan Piatu di Lembaga Kesejahteraan Sosial Anak Kabupaten Bireuen (n=104)

\begin{tabular}{|c|c|c|c|c|c|c|c|c|c|}
\hline \multirow{3}{*}{ No } & \multirow{3}{*}{ Variabel/Kategori } & \multicolumn{4}{|c|}{ Kekuatan } & \multirow{2}{*}{\multicolumn{2}{|c|}{ Total }} & \multirow{3}{*}{$\begin{array}{c}\text { OR } \\
(\mathrm{CI} 95 \%)\end{array}$} & \multirow{3}{*}{$\begin{array}{c}P \\
\text { Value }\end{array}$} \\
\hline & & \multicolumn{2}{|c|}{ Normal } & \multicolumn{2}{|c|}{ Abnormal } & & & & \\
\hline & & $\mathbf{n}$ & $\%$ & $\mathbf{n}$ & $\%$ & $\mathbf{n}$ & $\%$ & & \\
\hline \multirow[t]{4}{*}{8} & Jumlah saudara: & & & & & & & & \\
\hline & Tidak ada & 12 & 100.0 & 0 & 0.0 & 12 & 100.0 & - & - \\
\hline & 2-3 bersaudara & 32 & 82.1 & 7 & 17.9 & 39 & 100.0 & $\begin{array}{c}0.94 \\
(0.32- \\
2.74) \\
\end{array}$ & 0.911 \\
\hline & $\geq 4$ bersaudara & 43 & 81.1 & 10 & 18.9 & 53 & 100 & - & - \\
\hline \multirow[t]{3}{*}{9} & Pengalaman konflik: & & & & & & & & \\
\hline & Tidak mengalami & 85 & 86.7 & 13 & 13.3 & 98 & 100.0 & - & - \\
\hline & Mengalami & 2 & 33.3 & 4 & 66.7 & 6 & 100.0 & $\begin{array}{l}13.08 \\
(2.17- \\
78.71) \\
\end{array}$ & 0.005 \\
\hline \multirow[t]{4}{*}{10} & Kunjungan Keluarga: & & & & & & & & \\
\hline & Selalu & 24 & 88.9 & 3 & 11.1 & 27 & 100.0 & - & - \\
\hline & Sering & 35 & 83.3 & 7 & 16.7 & 42 & 100.0 & $\begin{array}{c}1.6 \\
(0.38- \\
6.81) \\
\end{array}$ & 0.525 \\
\hline & Jarang & 28 & 80.0 & 7 & 20.0 & 35 & 100.0 & $\begin{array}{c}2.0 \\
(0.46- \\
8.60) \\
\end{array}$ & 0.352 \\
\hline \multirow[t]{4}{*}{11} & Dukungan sosial: & & & & & & & & \\
\hline & Tinggi & 20 & 87.0 & 3 & 13.0 & 23 & 100.0 & - & - \\
\hline & Sedang & 58 & 85.3 & 10 & 14.7 & 68 & 100.0 & $\begin{array}{c}1.15 \\
(0.29- \\
4.60) \\
\end{array}$ & 0.844 \\
\hline & Kurang & 9 & 69.2 & 4 & 30.8 & 13 & 100.0 & $\begin{array}{c}2.96 \\
(0.55- \\
16.07)\end{array}$ & 0.208 \\
\hline
\end{tabular}

Berdasarkan analisis data pada Tabel 3, dapat diketahui bahwa terdapat hubungan antara status anak yatim piatu, kondisi kesehatan anak yang sakit, dan anak yang memiliki pengalaman konflik dengan penurunan perilaku prososial anak. Berdasarkan hasil uji statistik didapatkan bahwa anak yatim piatu lebih berisiko mengalami gangguan perilaku prososial 12 kali lebih besar dari pada status anak piatu atau yatim $(\mathrm{OR}=3.75 ; 95 \% \mathrm{CI}=1.05-13.40$; dan $p$ value 0.042$)$. Anak dengan kondisi sakit dapat terpapar gangguan perilaku prososial 9.11 kali lebih besar dibandingkan anak yang sehat $(\mathrm{OR}=9.11 ; \mathrm{CI}=1.39-59.47$; dan $p$ value 0.021$)$, dan anak yang mengalami pengalaman konflik 13.08 kali lebih terpapar masalah gangguan perilaku prososial dibandingkan anak yang tidak mengalami pengalaman konflik $(\mathrm{OR}=13.08 ; \mathrm{CI}=2.17-78.71$; dan $p$ value 0.005$)$.

\section{Analisis Multivariat}

Hasil analisis multivariat terkait determinan kesehatan mental anak yatim dan piatu di Lembaga Kesejahteraan Sosial Anak Kabupaten Bireuen, dapat disajikan dalam tabel 4. 
Hasil analisis Tabel 4 menunjukkan bahwa faktor risiko yang paling dominan mempengaruhi kesulitan mental emosional anak adalah keluarga yang jarang berkunjung ke panti asuhan, jenis kelamin perempuan, usia anak saat meninggal orangtua $\leq 5$ tahun, dan alasan masuk ke panti karena alasan lainnya (melanjutkan pendidikan, disuruh Ibu/Ayah, dan tidak mampu). Uji statistik menunjukkan bahwa anak yang keluarganya yang jarang berkunjung ke panti $(\mathrm{OR}=19.68 ; 95 \% \mathrm{CI}=2.81-137.81 ; \quad p$ value $=0.003)$, memiliki risiko mengalami kesulitan mental emosional 19.68 kali lebih besar dibandingkan anak yang keluarganya selalu atau sering berkunjung.

Hasil analisis menunjukkan bahwa anak perempuan lebih berisiko 11.15 kali lebih besar mengalami kesulitan mental emosional dibandingkan anak laki-laki (OR=11.15; 95\% $\mathrm{CI}=2.13-58.37 ; p$ value $=0.004$ ). Usia anak saat yatim dan piatu $\leq 5$ tahun memiliki risiko mengalami kesulitan mental emosional 5.72 kali lebih besar dibandingkan anak yang berusia 6 tahun ke atas $(\mathrm{OR}=5.72 ; 95 \% \mathrm{CI}=1.63-20.10 ; p$ value $=0.007$, dan anak yang masuk ke panti asuhan karena alasan lainnya (OR=4.53; 95\% $\mathrm{CI}=1.40-14.65 ; p$ value $=0.012$ ), memiliki risiko 4.53 kali lebih besar mengalami kesulitan mental emosional dibandingkan anak yang masuk panti karena alasan keinginan sendiri atau meninggal orangtua.

Berdasarkan analisis Tabel 4, menunjukkan bahwa faktor risiko yang paling mempengaruhi perilaku prososial anak adalah anak yang mengalami pengalaman konflik, status anak piatu, kondisi kesehatan anak yang sakit, dan alasan masuk ke panti karena alasan lainnya. Anak yang mengalami pengalaman konflik $(\mathrm{OR}=24.49 ; 95 \% \mathrm{CI}=3.14$ 190.75; $P$ value=0.002), memiliki risiko 24.49 kali lebih rendah berperilaku prososial dibandingkan anak yang tidak memiliki pengalaman konflik. Status anak piatu $(\mathrm{OR}=7.37$; 95\% CI=1.62-33.42; $P$ value $=0.010$ ), memiliki risiko 7.37 kali lebih rendah berperilaku prososial dibandingkan status anak yatim atau yatim piatu.

Kondisi kesehatan anak yang sakit memiliki risiko 14.72 kali lebih rendah berperilaku prososial dibandingkan anak yang sehat $(\mathrm{OR}=14.72,95 \% \mathrm{CI}=1.87-116.10 P$ value $=0.011$ ). sedangkan alasan anak masuk ke panti asuhan karena alasan lainnya $(\mathrm{OR}=4.49 ; 95 \% \mathrm{CI}=1.15-17.49 ; P$ value $=0.031)$, memiliki risiko perilaku prososial lebih rendah 4.49 kali dibandingkan anak dengan alasan keinginan sendiri dan meninggal orangtua.

Tabel 4. Analisis Multivariat Regresi Logistik Faktor Risiko Terhadap Kesulitan dan Kekuatan (Prososial) pada Anak di Lembaga Kesejahteraan Sosial Anak Kabupaten Bireuen

\begin{tabular}{|c|c|c|c|c|}
\hline No & Faktor risiko & Kategori & OR $(95 \%$ CI $)$ & $P$ value \\
\hline $\mathbf{A}$ & \multicolumn{4}{|c|}{ Kesulitan Mental Emosional } \\
\hline \multirow[t]{2}{*}{1} & \multirow{2}{*}{ Jenis Kelamin } & Laki-laki & - & - \\
\hline & & Perempuan & $11.15(2.13-58.37)$ & 0.004 \\
\hline \multirow[t]{2}{*}{2} & \multirow[t]{2}{*}{ Pendidikan } & SLTA & & \\
\hline & & SLTP & $3.31(0.74-14.87)$ & 0.118 \\
\hline \multirow[t]{3}{*}{3} & \multirow[t]{3}{*}{ Alasan masuk panti } & Keinginan sendiri & - & - \\
\hline & & Meninggal orangtua & - & - \\
\hline & & Lainnya & $4.53(1.40-14.65)$ & 0.012 \\
\hline \multirow[t]{3}{*}{4} & \multirow[t]{3}{*}{ Usia yatim dan piatu } & 11-18 tahun & - & - \\
\hline & & 6-10 tahun & - & - \\
\hline & & $\leq 5$ tahun & $5.72(1.63-20.10)$ & 0.007 \\
\hline \multirow[t]{2}{*}{5} & \multirow[t]{2}{*}{ Kunjungan keluarga } & Selalu & - & - \\
\hline & & Sering & $5.31(0.81-34.55)$ & 0.081 \\
\hline
\end{tabular}




\begin{tabular}{|c|c|c|c|c|}
\hline No & Faktor risiko & Kategori & OR $(95 \%$ CI $)$ & $P$ value \\
\hline & & Jarang & $19.68(2.81-137.81)$ & 0.003 \\
\hline B & Kekuatan (Perilaku & sial) & & \\
\hline \multirow[t]{3}{*}{1} & Alasan masuk panti & Keinginan sendiri & - & - \\
\hline & & Meninggal orangtua & & - \\
\hline & & Lainnya & $4.49(1.15-17.49)$ & 0.031 \\
\hline \multirow[t]{3}{*}{2} & Status anak & Yatim & - & - \\
\hline & & Piatu & $7.37(1.62-33.42)$ & 0.010 \\
\hline & & Yatim piatu & - & - \\
\hline \multirow[t]{2}{*}{3} & Kondisi kesehatan & Sehat & - & - \\
\hline & & Sakit & $14.72(1.87-116.10)$ & 0.011 \\
\hline \multirow[t]{2}{*}{4} & Pengalaman konflik & Tidak mengalami & - & - \\
\hline & & Mengalami & $24.49(3.14-190.75)$ & 0.002 \\
\hline \multirow[t]{3}{*}{5} & Dukungan Sosial & Tinggi & - & - \\
\hline & & Sedang & $0.35(0.08-1.49)$ & 0.154 \\
\hline & & Kurang & & - \\
\hline
\end{tabular}

\section{Pembahasan}

Berdasarkan hasil penelitian, menunjukkan bahwa prevalensi keseluruhan masalah kesulitan mental emosional responden sebesar 25\%. Aspek yang paling dominan adalah masalah teman sebaya. Dari hasil yang diperoleh diketahui bahwa anak-anak yang berada di panti lebih tertutup dan mereka lebih cenderung membentuk kelompok-kelompok sebaya dalam berinteraksi sosial. Namun, ada diantara mereka yang sulit beradaptasi dengan lingkungan baru dan lebih suka menyendiri, sehingga sering diganggu (bullying) oleh anak-anak lainnya. Beberapa anak yang tinggal di panti juga ada yang lebih suka berteman dengan orang yang lebih dewasa daripada yang seumuran dengannya, dalam hal ini mereka lebih terbuka dan nyaman berbagi cerita dengan guru atau pengasuh di panti asuhan.

Anak yatim piatu, pada umumnya memiliki masalah mental yang lemah karena meninggal ayah/ibu kandungnya atau bahkan kedua orangtua kandungnya. Ditambah lagi dengan berbagai masalah lain seperti ekonomi keluarga, masalah di lingkungan tempat tinggalnya, atau di sekolah. Oleh karena itu, anak yatim piatu yang memiliki hubungan teman sebaya yang positif lebih dapat mengatasi stres karena mendapat dukungan dari temantemannya, sedangkan hubungan teman sebaya yang negatif akan sering menimbulkan masalah perilaku, seperti tawuran, bullying, kenakalan remaja dan beberapa masalah perilaku menyimpang lainnya.

Hasil penelitian ini sejalan dengan penelitian Wiguna, et al. ${ }^{21}$, juga menemukan bahwa masalah teman sebaya dan emosi merupakan persentase terbesar dalam masalah perilaku dan emosional pada anak dan remaja. Studi serupa lainnya dalam yang dilakukan oleh Simsek, et al. ${ }^{16}$, prevalensi masalah emosional dan perilaku di antara anak-anak dan remaja yang diasuh di panti asuhan ditemukan lebih tinggi $(23,2 \%)$ dibandingkan dengan sampel komunitas representatif nasional dari anak-anak yang berusia sama yang dibesarkan dalam keluarganya sendiri (11\%). Di tempat lain, kajian masalah mental emosional anak di lingkungan keluarga yang dilakukan oleh Pademme, et al. ${ }^{14}$, pada remaja yang tinggal dalam keluarga inti ditemukan proporsi terbesar adalah masalah dengan teman sebaya (38.87\%), sedangkan prevalensi masalah perilaku keseluruhan sebesar $17.84 \%$, aspek gejala emosional $25.80 \%$, masalah perilaku $24.38 \%$, hiperaktivitas $9.72 \%$, dan perilaku prososial $2.83 \%$. Beberapa penelitian ini sama-sama mengungkapkan bahwa masalah terbesar anak remaja pada umumnya adalah masalah teman sebaya. Dalam kelompok teman sebaya, anak akan menemukan jati diri serta dapat mengembangkan rasa sosialnya ketika berinteraksi dengan teman sebayanya. Memungkinkan juga bagi mereka untuk bertukar pikiran dan pengalaman, serta memberi 
semangat atau motivasi terhadap teman sebaya yang lain secara emosional. Ikatan emosional dalam kehidupan teman sebaya akan mendatangkan berbagai manfaat dan pengaruh yang besar bagi individu yang berada dalam kelompok tersebut.

Hasil analisis menunjukkan bahwa yang menjadi faktor risiko responden mengalami kesulitan masalah mental emosional adalah faktor jenis kelamin perempuan, faktor alasan lainnya (disuruh ibu/ayah/keluarga, melanjutkan pendidikan, dan tidak mampu), Usia anak saat yatim dan piatu $\leq 5$ tahun, dan faktor keluarga yang jarang berkunjung. Penelitian ini sejalan dengan temuan dari penelitian Kaur, et al. ${ }^{6}$, yang menunjukkan bahwa $16,78 \%$ anak dan remaja mengalami masalah perilaku dan emosional. Faktor usia, jenis kelamin, alasan berada di panti asuhan, usia masuk, dan tahun tinggal di rumah asuhan semuanya berhubungan secara signifikan $(P<0,05)$ dengan masalah emosional dan perilaku. Masalah perilaku ditemukan paling dominan $(34,90 \%)$, yang selanjutnya diikuti oleh masalah teman sebaya $(15,80 \%)$, masalah emosional $(14,70 \%)$, hiperaktif $(8,60 \%)$, dan perilaku prososial rendah $(3,40 \%)$.

Pernyataan Santrock ${ }^{15}$, juga menjelaskan bahwa remaja putri memiliki tingkat depresi yang lebih tinggi dibandingkan remaja putra. Beberapa penyebab dari perbedaan antar jenis kelamin ini adalah: (1) remaja putri cenderung tenggelam dalam depresi mereka; (2) self image dari remaja putri cenderung lebih negatif dibandingkan remaja putra; (3) masa puber lebih cepat terjadi pada remaja putri, sehingga mereka mengalami berbagai perubahan pengalaman hidup yang sangat banyak pada masa-masa SMP, yang dapat meningkatkan depresi.

Penelitian ini, diketahui pula bahwa faktor keluarga yang jarang berkunjung ke panti memiliki risiko 19.68 kali lebih besar mengalami kesulitan mental emosional dibandingkan anak yang keluarganya selalu atau sering berkunjung. Ada salah satu anak mengaku bahwa ia tidak pernah dikunjungi oleh keluarganya lagi semenjak ia pertama kali diantar ke panti asuhan. Menurut Wahyuningrum and Tobing ${ }^{20}$, dalam artikelnya menyatakan bahwa kebanyakan orang tua memasukkan anak ke panti asuhan karena kesulitan ekonomi dan juga secara sosial dalam konteks tertentu, dengan tujuan untuk memastikan anak-anak mendapatkan pendidikan yang layak. Maka anak/remaja ini memilih tinggal di panti asuhan karena orangtua mereka tidak mampu membiayai sekolah mereka.

Uji statistik multivariat faktor risiko yang paling berhubungan dengan kekuatan/perilaku prososial masalah kesehatan mental responden adalah faktor alasan masuk panti kategori lainnya, faktor status anak piatu, faktor kondisi kesehatan anak yang sakit dan faktor anak yang mengalami pengalaman konflik. Temuan ini sejalan dengan penelitian yang telah dilakukan oleh Bhat et al., bahwa status anak (yatim, piatu, yatim piatu) memiliki hubungan yang signifikan dengan kesehatan anak di panti asuhan.

Dalam keluarga, ayah dan ibu memiliki peran penting dalam pengasuhan anak, ketika peran ayah atau ibu, atau keduanya hilang dalam keluarga, maka bisa mengembangkan psikopatologi. Meninggalnya ibu dapat menyebabkan terputusnya ikatan (attachment) yang paling utama. Trauma ini dapat terulang bila pengasuhan anak dialihkan kepada orang lain untuk kedua kalinya. Perpisahan yang traumatis dapat menyebabkan anak tumbuh menjadi orang dewasa yang rendah diri, sulit mempercayai orang lain, enggan berumahtangga, dan kurang kematangan moral dan sosial ${ }^{3}$.

Penelitian ini menemukan bahwa anak yang memiliki riwayat atau pengalaman konflik (korban konflik di Aceh, KDRT, dll) memiliki risiko mengalami penurunan perilaku prososial dibandingkan anak yang tidak memiliki pengalaman konflik. Hasil wawancara mengungkapkan bahwa beberapa anak yang di bawa ke panti asuhan berasal dari Dinsos Pemerintah Daerah. Beberapa diantara mereka ada yang berlatar belakang masuk ke panti karena pengalaman konflik atau masalah dalam keluarga. Sehingga anak tersebut terkadang lepas kendali, dan pernah ada anak yang kabur dari panti asuhan ketika lepas dari pengawasan pengurus panti. Hal ini terjadi karena mereka belum mampu beradaptasi dengan lingkungan baru, ditambah dengan emosional yang belum stabil. 
Penelitian lokal yang dilakukan oleh Jannah ${ }^{5}$, di markaz al Aziziyah Lueng Bata Banda Aceh, menunjukkan bahwa anak-anak korban konflik di aceh tidak mengalami gangguan psikis yang berat karena mereka memiliki keimanan yang kuat meski dalam perilaku mereka terganggu, namun tidak sebanding dengan trauma yang mereka hadapi. Namun trauma yang mereka hadapi termasuk dalam delay traumatic yang suatu saat akan muncul kembali. Gejala trauma dapat dilihat dari 4 aspek yaitu: (1) fisik, (2) kognitif, (3) afektif (emosi), dan (4) perilaku. Pada perilaku, gejala trauma yang sering dimunculkan adalah menolak, malas bergaul (antisosial), malas, tidak suka kegiatan, menjadi pendiam atau pemarah, kehilangan nafsu makan, terlalu peka dengan lingkungan, menggunakan alkohol/obat-obatan, perubahan pola perilaku, buang air kecil pada malam hari, dan tergencit. Berdasarkan empat aspek di atas, maka dapat dikatakan anak-anak akan mengalami tanda-tanda trauma seperti hal tersebut. Akan tetapi tidak semua gejala-gejala trauma di atas dialami oleh anak-anak.

\section{Kesimpulan}

Berdasarkan penelitian yang telah dilakukan, dapat disimpulkan bahwa terdapat beberapa masalah mental emosional pada anak yatim dan piatu di Lembaga Kesejahteraan Sosial Anak Kabupaten Bireuen tahun 2020, dan beberapa faktor yang paling berpengaruh terhadap kesulitan mental emosional anak yatim dan piatu adalah faktor jenis kelamin perempuan, alasan masuk ke panti asuhan karena alasan lainnya lainnya (disuruh ibu/ayah/keluarga, melanjutkan pendidikan, dan tidak mampu), status anak yatim piatu dan keluarga yang jarang berkunjung. Sedangkan faktor risiko yang paling berhubungan dengan faktor kekuatan/perilaku prososial masalah kesehatan mental responden adalah faktor alasan anak masuk ke panti asuhan karena alasan lainnya, status anak piatu, kondisi kesehatan anak yang sakit, dan anak yang mengalami pengalaman konflik.

\section{Saran}

Disarankan bagi seluruh pengurus panti dan pengasuh untuk meningkatkan pelayanan kebutuhan dasar maupun kebutuhan psikososial pada anak-anak, seperti perhatian dan dukungan sosial, sehingga terbina hubungan kekerabatan layaknya dalam sebuah keluarga inti, agar anak merasakan nyaman tinggal di panti asuhan dan masalah psikososial dapat diminimalisir.

\section{Daftar Pustaka}

1. Nurulwahida Hj Azid, and Aizan Yaacob, 2016. 'Enriching Orphans' Potentials through Interpersonal and Intrapersonal Intelligence Enrichment Activities', International Journal of Instruction, 9, 17-32.

2. AA Bhat, Sadaqat Rahman, and NM Bhatt, 2015. 'Mental Health Issues in Institutionalized Adolescent Orphans', Int J Indian Psychol, 3, 57-77.

3. Children's Services Practice Notes, 'Effects of Attachment and Separation', Jordan Institute for Families, (1997)

4. Donald E Greydanus, and MD Joav Merrick, 2012. 'Adolescent Mental Health', International Journal of Child Health and Human Development, 5, 143.

5. Miftahul Jannah, 'Trauma \& Tazkiyatun Nufus, 2017. (Pada Santri Korban Konflik Di Markaz Al-Aziziyah Lueng Bata Banda Aceh)', Gender Equality: International Journal of Child and Gender Studies, 2, 69-80.

6. Ravneet Kaur, Archana Vinnakota, Sanjibani Panigrahi, and RV Manasa, 2018. 'A Descriptive Study on Behavioral and Emotional Problems in Orphans and Other Vulnerable Children Staying in Institutional Homes', Indian Journal of Psychological Medicine, 40, 161. 
7. Sukhminder Kaur, and C Rani, 2015. 'Exploring Psychological Health of Orphan Adolescents: A Comparative Analysis', International Journal of English Language, Literature and Humanities, 3, 27-47.

8. Kemenkes RI, 2018. Kurikulum Tot Keterampilan Kecakapan Hidup Bagi Kesehatan Jiwa Anak Dan Remaja (Jakarta: Direktorat Pencegahan dan Pengendalian Masalah Kesehatan Jiwa dan NAPZA, Ditjen Pencegahan dan Pengendalian Penyakit, Kementerian Kesehatan RI.

9. - 2019. Laporan Provinsi Aceh Riskesdas 2018 (Jakarta: Lembaga Penerbit Badan Litbang Kesehatan.

10. —— 2016. 'Peran Keluarga Dukung Kesehatan Jiwa Masyarakat', Kementerian Kesehatan Republik Indonesia.

11. Simon Kyaga, Mikael Landén, Marcus Boman, Christina M Hultman, Niklas Långström, and Paul Lichtenstein, 2013. 'Mental Illness, Suicide and Creativity: 40-Year Prospective Total Population Study', Journal of Psychiatric Research, 47, 83-90.

12. Stine Lehmann, Odd E Havik, Toril Havik, and Einar R Heiervang, 2013. 'Mental Disorders in Foster Children: A Study of Prevalence, Comorbidity and Risk Factors', Child and adolescent psychiatry and mental health, 7, 39.

13. M. Mohammadzadeh, H. Awang, H. Kadir Shahar, and S. Ismail, 2018. 'Emotional Health and Self-Esteem among Adolescents in Malaysian Orphanages', Community Ment Health $J, 54,117-25$.

14. Dirgantari Pademme, Retno Sutomo, and Lely Lusmilasari, 2018. 'Profil Dan Faktor Yang Berhubungan Dengan Masalah Perilaku Pada Remaja Di Kota Sorong Papua Barat', Sari Pediatri, 19, 189-95.

15. John W Santrock, 2007. 'Perkembangan Anak', Jakarta: Erlangga.

16. Zeynep Simsek, Nese Erol, Didem Öztop, and Kerim Münir, 2007. 'Prevalence and Predictors of Emotional and Behavioral Problems Reported by Teachers among Institutionally Reared Children and Adolescents in Turkish Orphanages Compared with Community Controls', Children and Youth Services Review, 29, 883-99.

17. John Stover, Lori Bollinger, Neff Walker, and Roland Monasch, 2007. 'Resource Needs to Support Orphans and Vulnerable Children in Sub-Saharan Africa', Health policy and planning, 22, 21-27.

18. UNICEF, 2011. The State of the World's Children 2011-Executive Summary: Adolescence an Age of Opportunity, Unicef.

19. Charlotte Waddell, Kimberley McEwan, Ray DeV Peters, Josephine M Hua, and Orion Garland, 2007. 'Preventing Mental Disorders in Children: A Public Health Priority', Canadian Journal of Public Health= Revue Canadienne de Sante Publique, 98, 174.

20. Enjang Wahyuningrum, and Maria Agustina Tobing, 2014. 'Pengasuhan Pada Remaja Yang Tinggal Di Panti Asuhan', Psychology Fair. Semarang.

21. Tjhin Wiguna, Paul Samuel Kris Manengkei, Christa Pamela, Agung Muhammad Rheza, and Windy Atika Hapsari, 2016. 'Masalah Emosi Dan Perilaku Pada Anak Dan Remaja Di Poliklinik Jiwa Anak Dan Remaja Rsupn Dr. Ciptomangunkusumo (Rscm), Jakarta', Sari pediatri, 12, 270-7.

22. Gregory D Zimet, Nancy W Dahlem, Sara G Zimet, and Gordon K Farley, 1988. 'The Multidimensional Scale of Perceived Social Support', Journal of personality assessment, $52,30-41$. 